\title{
Branding Strategy for Non - Profits in Developing Countries: Case Study - Albania
}

\author{
Alkida Hasaj, PhD candidate \\ Lecturer, University of Shkodra "Luigj Gurakuqi", Faculty of Economy, \\ Department of Marketing - Tourism, Shkoder, Albania \\ Ervis Krymbi, PhD Candidate
}

Lecturer, University of Shkodra "Luigj Gurakuqi", Faculty of Social Science,

Department of Geography, Shkoder, Albania

\author{
Doi:10.5901/ajis.2013.v2n9p351
}

\section{Abstract}

Regardless developed or in developing countries, the world has experienced a sudden expansion of the Non - Profit sector in recent decades. This happen because the non-profit sector is very important for the whole scheme of a country life and the rapid changes in environmental conditions. Actually dozens of nonprofit organizations operate also in Albania. However, the increase in the number of these third sector organizations has not been accompanied by an equal growth in the availability of human and financial resources. This has led to an increase in competition between nonprofit organizations for the limited sources of revenue and volunteers available. As nonprofit sector has become more competitive it is important to be able to build strong brand identity, image and personality in order to differentiate themselves in the growing nonprofit sector. In this study the two main concerns are, branding and increased competition between nonprofits. So the purpose for this study is to demonstrate the use of brand management to create distinction, and the challenges of merging branding methodologies into nonprofit organizations that operate in Albania. The data to conduct this paper were collected from the contemporary literature in this field and using a qualitative research through in depth interviews with managers of a nonprofit organization that operate in North Albania - "I CARE". Results demonstrate there is more informal than a formal process to evaluate its brand by nonprofit organization that operates in North Albania.

Keywords: Non-Profit Organizations, Competition, Branding, Challenge, Marketing.

\section{Introduction}

The non-profit sector is very important for the whole scheme of a country life. Dozens of non-profit organizations actually operate in Albania. During the last 20 years there has been a significant increase in the number of non-profit organizations, because of the rapid changes in environmental conditions. As a result there is a growth in competition among organizations that operate in this sector.

As nonprofit sector has become more and more competitive in seeking sources of revenue and volunteers, it is important to be able to build strong brand identity, image and personality in order to differentiate themselves in the growing nonprofit sector (Hasaj.A and Kruja.D, 2012).

The use of branding in traditional for-profit organizations has led to well recognized logos and company names that have become a part of everyday culture. Brands become important during 1990 for nonprofit companies too, in order to differentiate themselves. As result, nonprofit management has borrowed age-old marketing strategies from mainstream corporations to increase awareness and effectively compete against all force that seek contributions. So the commercialization of non-profit organizations through marketing mechanisms has recently become important.

By surveying relevant issues confronting nonprofits, such as the new paradigm for strategic management, a greater understanding into key issues facing nonprofits survival in the 21 century can be uncovered. Another core element of relevancy lies in the commercial value of any organization's message. The sheer number of communiqués in both the commercial and nonprofit world has vastly increased and diluted the meaning of any one brand. In response, nonprofits have turned to traditional marketing theories and practices in order to differentiate themselves to compete for scarce resources.

In consideration of these challenges, a case study was developed to examine the brand management utilized by a nonprofit and strategies employed to combat the new landscape of competition. 
So the purpose for this study is to demonstrate the use of brand management to create distinction, and the challenges of merging branding methodologies into nonprofit organizations that operate in Albania.

The data to conduct this paper were collected from the contemporary literature in this field and using a qualitative research through in depth interviews with managers of a nonprofit organization that operate in North Albania - "I CARE".

\section{Branding in Nonprofit Organization and Definitions}

Given the intention to examine the brand management practices to the nonprofit organizations, it is important to begin by defining what we mean by this term. The nonprofit organizations can be defined as an institution that exists to provide for the general welfare of society, through the marshalling of appropriate resource and/ or the provision of physical goods and service. Such organizations do not exist to provide for personal profit or gain and do not, as a result, distribute profits or surpluses to shareholders or members. They may, however, employ staff and engage in revenue-generating activities designed to assist them in fulfilling their mission (Sergante, 2009).

Traditionally, nonprofit organizations relied on three sources of revenue: governmental support, voluntary donations and grants. Until the late 1970s, the federal government was the single largest supporter of charitable nonprofit organizations in the world (Borman, Anne and Clarence Lo, 1995).

Nonprofit organizations now face a scenario familiar to the for-profit sector: just as for-profit businesses compete for consumers, demand, nonprofits have to compete for the donation capacity of the philanthropic community, and only the most visible succeed (McDanel, William G, 1983). The concept of branding presents nonprofits with new opportunities to address competition and to increase contributed and earned income.

Brands have always been vital to the promotion and selling of products throughout history. The term "brand" is a name, term, symbol or design (or a combination of these) which is intended to indentify the product or services of one seller or group of sellers. A brand name serves to differentiate a product from those of its seller competitors ( $\mathrm{J}$. Sutherland and D. Canwell, 2004. P. 42). A brand can symbolize a product, a service, or the organization itself (Andreasen R. Alan, 2008. 166). James Twichell likens branding to storytelling and argues that much of what we know about ourselves comes through brand (James Twicheller, 2004).

The Brand Strategy Doctrine is the process for developing and communicating a brand identity. It consists of a detailed strategy for designing, creating, and communicating intended brand perception. In addition, it defines the character, style, and collective architecture (name, byline, graphic representation, etc.) of the brand. The outcome from this activity delivers a set of perceived values that the organization wants to reside in the consumer's mind eye. Al Ries and Jack Trout (Ries, 1994) said brand it best - "perceptions, not products." The net result of this process ensures that all elements support "what the brand stands for" and that the desired perception is achieved.

Whether there is a new organization going through the critical process of finalizing their mission statement, or a mature organization trying to integrate and redefine their online and offline personality, branding is an important part of a nonprofit's identity.

As stated in a Harvard University discussion paper, "Effective branding is becoming a central concern of leaders across the nonprofit sector as many nonprofit managers feel increasing competition from other nonprofits, for-profit businesses, and new organizations that claim to blur the boundaries between nonprofit, for-profit, and public sectors" (Thomas Remya, 2012).

Private sector marketers spend enormous amounts building and defending their brand. Nonprofit organizations are coming to realize that they have much to learn from their experiences (Andreasen R. Alan, 2008. 167).

There are breadths of issues facing nonprofit organizations today. As it noted by searching, nonprofits face a multitude of issues including government legislation, competition, accountability, management effectiveness, and adapting to the changing marketplace of donors. Nonprofits attempt to balance the need to raise funds, provide satisfaction to donors, and serve the public trust, can best be captured in the societal marketing theory. As nonprofits face this new competitive threat, several issues are raised concerning the viability of nonprofit's purpose and underlying values to society. If nonprofits shed their inherent role to care for the community and switch to a corporate mindset, many vital services and reinvestment into the community will be lost. So, not everyone in the nonprofit sector thinks that an emphasis on organizational branding and positioning is a good idea for nonprofits (Spruill Vikkki, 2001. 45-46).

The nonprofit world - especially advocacy groups working in fields such as health, education, and the environment - can ill afford to wage corporate-style branding battles. Instead of helping charitable groups work together to build a broad base of support from donors, volunteers and activist, branding becomes a barrier. It foster unhealthy competition among nonprofit groups for visibility, promotes the hoarding of proprietary information, and leaves donors confused about how their support is making a difference. 
The idea that a nonprofit would perform like a for-profit in order to differentiate itself, it can cause competition and perhaps result in questionable practices by nonprofit leaders.

But expect this, Kevin Lane Keller (2003), an expert on branding, explain that an organization's branded offerings can serve several role:

- Reflect a unique social contribution,

- Comprise a promise to target audiences and stakeholders,

- Reflect the organization's mission and values.

Indentifying a nonprofit brand as having high value can motivate various stakeholders to contribute more - work harder, volunteer more, donate more and reap personal pleasure from involvement with such a powerful and highly valued institution.

Nonprofits that are perceived to have clear, identifiable social good values in sync with its mission are at a strategic advantage over ones with vague goals or unclear identities. There are different approaches to a successful branding process, but the main goal should be to start, or continue, a conversation to build a lasting relationship with stakeholders.

A study of consumer trust in brands in Europe and United States by Edelman Public Relations found that the top four most trusted brands in Europe were actually nonprofits (Andreasen R. Alan, 2008. 171). Another study conducted by Edelman on people trust revealed that the total levels of trust for nonprofit organizations rise from $58 \%$ in the year 2012, to $63 \%$ in 2013. This result is higher than the total level of trust in 2013 for government institutions with a result of $48 \%$, business with a result of 58\% and media with a result of 57\% (Edelman Trust Barometer, 2013).

\section{Research Method}

The purpose of this research was to examine if brand management create distinction, and the challenges of merging branding methodologies in the nonprofit organization "I CARE", a nonprofit organization that operate in North Albania at Shkodra city, Albania.

According to Merriam (1988) a case study is a format in which the researcher explores a single entity or phenomenon ("the case") bounded by time and activity (a program, event, process, institution, or social group) and collects detailed information by using a variety of data collection procedures during a sustained period of time.

The application of qualitative research consisted of in-depth interviews with organizational members. In addition, a review of their collateral material, financial statements, press releases, and other promotional materials was examined for content and message. Senior management was targeted for interviews since they are responsible for the vision and mission of the business as well as other key individuals who have direct input into the generation of promotional materials.

The site location for this study was primarily located at the office of the "I CARE" organization in Shkodra, Albania. An in-depth interview technique was used, which consisted of unstructured, open - ended questions to solicit an understanding of how the organization perceives itself. These questions are geared toward uncovering the perceptions and attitudes the collective governing body has about their vision, mission, and strategies to achieve both short and longterm goals. This approach was developed to gain a deeper understanding of the issues their brand faces and by which process they solve their problem.

The secondary data were also used in this study which was achieved through an extensive literature review on the brand management practice of nonprofit organizations, but what was achieved through this data was only theoretical.

\section{Case Study}

To consider the brand management in nonprofit organization it was considered as example "I CARE", a nonprofit organization that operate in Shkoder, Albania.

The idea to create this nonprofit organization was initiated on the year 2008, in Shkodra city, during the visit of Michele Gesualdi, one of the students of Don Dalan a Catholic priest who all his life dedicated to the youth from the area of Barbia in Italy. During the moment of signing the establishment chart a very important person participated and sustained the creation of this association and he was Don Carlo Zaccoro.

Currently the number of registered members who voluntary support the activities of this organizations, are over 20 people. This society, for the third year organizes in area of Shllak, in collaboration with Dom Ardian Arra, summer camps with children from this area. Other activities that they develop are: Recovery School, Animation and Collective Lunch. The main partners of "I Care" organizations that help in organizing of these activities are associations like: Mosaico, Misericodria, Madonnina Del Grappa. 
The vision of the nonprofit organizations, "I Care" is:

"God has given us hope and our task is to organize it. Difficult times are not moment to cry, but to turn the hardship in force, in desire to live, in happiness through friendship, forgiveness and love".

The mission of "I Care" is:

"To dedicate our lives to the poorest, humbles, loneliest, those who have no support, those who the society has abandoned and excluded".

Which are other activities that "I Care" organizes? One other major social project is "I and the other". It was called by this name, based in the mission that the organization have. "We do not conceive our life, without the other...". Whereby this project, "I Care" wants to come in helps of children's who lives in periphery of the city and suffering from malnutrition problems.

This project was launched in February 2008, and during the period of school attendance it become possible to be given a warm lunch about 90 children per day. The nonprofit organization "I care" currently operate with the children of the poor families who attend the school "Ndoc Mazi" and children who continue to attend the activity near the center "Ravasko" at the train station.

The nonprofit organization "I Care" and the emergency group "Sacra - Vita", in collaboration with Shkodra Prefecture, on 08.01.2010 have provided assistance in one of municipalities of Shkodra region, as result of floods. During this period the association "I care - Sacra Vita" has contributed serving food to Egyptian community.

Other activities:

"I Care" in cooperation with the nonprofit organization "Madonnina del Grappa", 'ACLI-IPSIA", and "RAVASCO", has implemented a project funded by the municipality of Forli - Italy and supervised by Shkodra municipality. This project aimed to support 20 girls taken from Shkodra Child Home (children without parent), and rehabilitating them at "Family Homes". "I Care" covered the psychological - educative aspects of this project, with a skilled staff of seven people.

"I Care" has covered psychological and social aspects also of a project, which was organized by a nonprofit organization "VIS" and has been supported by MAE (Ministry of Foreigner Affair), Italy. This project it was implemented in the area of Tamar, Lepurushes and Kelmend. "I Care" gave its contribution with three young psychologists.

Currently, the volunteers of "I Care" are taking part in different courses in the field of sociology, in order to increase their capacity to work and serve people in need, everyday. These courses are supported by "ACLI-IPSIA", "SHIS", and "Ë.V", "CARISTAS", etc.

"I Care" in Shkodra city, operates on the basis of Albania legislation on NPO (Nonprofit Organization). But they consider that Albania legislation is not really in favor of nonprofit organizations that operate in this country. If they develop economic activity to fund its operations they are treated as businesses and not as social initiatives.

Recently in Albania are operating more and more NPO, which have a positive impact in this country. But the competition might be considered in the situation when there is the need to win grants, and the one who finds these has been the most successful. For "I Care" more than competition, this means also collaboration with other NPO, because all are working to improve social condition. It is the mentality of cooperation, what differentiates "I Care" organization from its competitor. But to have a greater collaboration is essential to build a local infrastructure and a network with other nonprofit organizations. For this reason "I Care" has sought dialogue with other organizations.

Nonprofit organizations now are facing a scenario familiar to the for-profit sector; nonprofits have to compete for the donation capacity of the philanthropic community. The concept of branding presents nonprofits with new opportunities to address competition and to increase contributed and earned income. The brand used by "I Care" is simple and explain that the organization care for all people especially fort them that are in need. For "I Care" organization in Shkoder city, his brand means "I Take Care for You". This brand was created based on the motto of Don. Dalani.

"In a society that is pushing towards individualism and selfishness, this brand calls the youth to care for those who are in need. A society cannot be considered such as they are, if they do not take in consideration the problems of the others".

On the figure number 1, the heart at the top of the letter (i) means love, heart and sustain. Shkoder, Albania means where the center of operations of this organization is. What it means read color? Red is the color of power and passion. Haller says it can also be linked to excitement, energy, and physical courage (Stanger.M, 2012). 


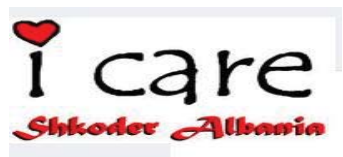

Figure 1. The branding name of "I Care" nonprofit organization.

"I Care" has had less experience with branding at the campaign level. They see their positioning challenge at the organization level to be one of differentiating their brand so as to get more donations, more volunteers, and more support from business organizations and politicians. "I Care" organization appreciate that their brand from 1 (one) to 10 (ten), has 7 (seven) positive impact of its brand in the eyes of donors, government and volunteers.

Developing, nourishing, and maintaining a brand is a challenge task. For many organizations that place great emphasis on their brand, it must be a continuing focus. The organization "I Care", do not have a single person responsible to develop his brand, but all the employees in this organization try to contribute on this aspect. The organization explains to the new employees the vision, mission and the meaning of their brand, "I Care".

Not all branding today among nonprofit organizations is at the organizational level, and for "I Care" organization is the same. Responsible for the graphic presentation of the brand for this organization is outsourcing, and currently is served by "Rozafa Print and Design" a agency that operetta in Shkoder. A well designed brand image is no longer a 'nice to have', but of incredible value to the organization. A strong brand image conveys an appealing and consistent image across mediums, stimulates engagement, confirms credibility and ultimately motivates action and advocacy for the nonprofit.

The nonprofit- branding don't understand marketing of branding and see it as some kind of violation of charitable purity. This is one of the reasons why it has little initiative from "I Care" in Shkoder, Albania for promoting their brand. They don't have also the experience or understanding to deliver effective branding strategies. However, spending human and financial resources on this important task is a low priority, often regarded as a frivolous investment. small!

Branding is important for social change, not just fundraising! Barding is important to all organizations, large or

\section{Conclusions}

In this paper, it was reviewed the background of the competition in the nonprofit sector discussing nonprofit branding as a potential solution to achieve long-term competitive advantages in order to increase a nonprofit's chances of survival and the challenges of merging branding methodologies into nonprofit organizations that operate in Albania. It was considered the example "I Care" organization that operates in North Albania.

The idea to create this nonprofit organization was initiated on the year 2008, in Shkodra city. The activities that "I Care" organizations develop are: Recovery School, Animation and Collective Lunch. Currently the number of registered member who voluntary support the activities of this organizations, are over 20 people The main partners of "I Care" organizations that help in organizing of these activities are associations like: Mosaico, Misericodria, Madonnina Del Grappa.

To conduct this research it was employed case study method and a case study was created about "I Care" organization in Shkoder region, Albania. The case studies method is considered useful in research as they enable researchers to examine data at the micro level. Although case studies have various advantages, in that they present data of real-life situations and they provide better insights into the detailed behaviors of the subjects of interest, they are also criticized for their inability to generalize their results.

The ability of an organization to thrive and stay relevant in the marketplace is difficult. "I Care" organization in Shkoder, Albania operates primarily in a specialized or niche market. For "I Care" the word competition means somewhat collaboration with other NPO, because all are working to improve social condition. And the mentality to cooperate is what differentiates "I Care" organization from its competitor. But to have a greater collaboration is essential to build a local infrastructure and a network with other nonprofit organizations. For this reason "I Care" has sought dialogue with other organizations.

They also consider important the concept of branding because presents nonprofits with new opportunities to address competition and to increase contributed and earned income. For "I Care" brand means standard and quality. But the nonprofit branding process has the difficulty to implement. The uniqueness of the environment and the added difficulty 
of branding in the nonprofit sector compel nonprofit organizations to develop more creative strategies and solutions. Branding strategies borrowed from for-profit businesses are not always applicable in the nonprofit setting.

During the assessment, it was clear that "I Care" organization in North Albania is lacks of a formal process to evaluate its brand. Although the organization possessed a clear vision, mission, and philosophy statements, no observable process was observed that reflected on the current state of the brand. A brand audit and a competitor analysis will give to the nonprofit organization a good sense of (1) the qualities that differentiate them from the competitors (2) any inconsistencies in major public-facing expressions of their brand, like the website or brochures (3) opportunities that are being under-utilized, which could lead to expanded services or increased donor pool (4) improved cohesion of their internal and external messaging and its lasting resonance.

In closing, "I Care" organization in Shkoder, Albania, could enhance its brand perception in this area by employing the Brand Strategy Doctrine. Developing, nourishing, and maintaining a brand is a challenge task. For "I Care" organizations placing a great emphasis on their brand, it must be a continuing focus.

\section{References}

Andreasen A,(2008) Strategic Marketing for Nonprofit Organizations, Seventh Edition, Pearson Education, pp. 166-171.

Borman A, Clarence L, ((August 1995) Can Not-For-Profits Learn from For-Profits?. Fund Raising Management, vol. 26, pp. 24-27.

Hasaj.A and Kruja.D (June, 2012), "The Marketing Concept: Market Orientation and the Performance of Nonprofit Organizations in Albania", Society Internationalization-Effectivity and Problem, No. 2, pp. 195

http://www.slideshare.net/Edelmanlnsights/2013-edelman-trust-barometer-global-financial-services-industry

Keller Lane Kevin, (2003), "Strategic Brand Management", 2nd ed. (Upper Saddle River, Nj: Prentice-Hall)

McDanel, William G, (August 1983) Marketing for Fund Raisers: Developing a New Sensibility.. Fund Raising Management, vol. 14, pp. 56-60.

Merriam, S.B. (1988) Case Study Research in Education: A qualitative Approach. San Francisco: Jossey-Bass.

Ries, Al. Trout, Jack. (1994) Immutable Laws of Marketing Free Press, pp.10

Sayre, Shay, (2001) Qualitative Methods for marketplace research Sage p.81-87

Sergante, A (2009). Marketing Mangement for nonprofit organizations. (ISBN: 978-0-19-923615-2), p 3.

Spruill V, (June 14, 2001) "Build Brand Identity for Cause, Not Groups, "The Chronicle of Philanthropy, pp.45-46.

Stanger. M, 29.12.2012, "How Brands Use The Psychology Of Color To Manipulate You", http://www.businessinsider.com/brandingand-the-psychology-of-color-2012-12?op=1

Sutherland. Jonathan and Canwell. Diane, (2004) Key concepts in Marketing, First Published by Palgrave Macmillan, pp. 42

Thomas. Remya, (February 13, 2012) "Four Stages of a Nonprofit Branding Cycle", http://conceptlink.com/ngo-branding

Twicheller J, Brand Nation (New York: Simon and Schuter, 2004) 